\title{
Efektivitas Minyak Atsiri Serai Untuk Pengendalian Penyakit Mosaik Kacang Panjang
}

\author{
Supyani1), Salim Widono1), Ulfaizah²)
}

\begin{abstract}
Production of cowpea has declined, one of them caused by virus infection that caused mosaic disease which was still difficult to controlled. This study aimed to determine the effectivity of antiviral compounds on lemongrass essential oils to development of mosaic disease and the relationship to growth and development of cowpea that infected. This study used Completely Randomized Design (CRD) with two factors, they are the time of application and concentration of lemongrass essential oil. Data were analyzed using $\mathrm{F}$ test and DMRT at level of $5 \%$. Results showed that application of lemongrass essential oil at concentration of $1,8 \%$ before planting (soaking seeds) tend to delaying the emergence of mosaic disease symptoms. Application of lemongrass essential oil at all of concentration that used, can inhibiting the disease intensity up to $31.39 \%$. However, apllication of lemongrass essential oils in plants infected with a virus that causes mosaic has not able to improve plant growth and development.
\end{abstract}

Keywords: antiviral compounds, incubation period of mosaic disease, intensity of mosaic disease

\section{PENDAHULUAN}

Kacang panjang merupakan salah satu sayuran yang dibudidayakan petani dan banyak dikonsumsi oleh masayarakat di Indonesia, tetapi dalam kurun waktu lima tahun terakhir produksi kacang panjang cenderung menurun. Berdasarkan data, produksi kacang panjang nasional tahun 2011 sampai 2015 yaitu 458.307 ton, 455.615 ton, 450.859 ton, 450.709 ton dan 399.078 ton (Kementrian Pertanian 2016). Penurunan produksi kacang panjang salah satunya disebabkan virus penyebab penyakit mosaik. Penyakit mosaik dapat disebabkan oleh infeksi virus tunggal atau campuran, diantaranya MYMIV (Mungbean yellow mosaic indian virus) (Nurulita et al. 2015), BCMV-BIC (Bean common mosaic virus strain black eye cowpea) dan CMV (Cucumber mosaic virus) (Damayanti et al. 2009).

Penyakit mosaik pada berbagai varietas kacang panjang yang disebabkan infeksi BCMV mengalami penurunan produksi polong 27,05$85,15 \%$ (Susetio dan Hidayat 2011) dan memperlambat kemasakan polong (Damayanti dan Hamdayanti 2014). Tahun 2009, penyebaran penyakit mosaik kacang panjang meluas di

1) Undergraduate Student of Study Program of Agrotechnology, Faculty of Agriculture, Sebelas Maret University (UNS) on Surakarta.

2) Undergraduate Student of Study Program of Agrotechnology, Faculty of Agriculture, Sebelas Maret University (UNS) on Surakarta.

Contact Author: ulfaizah94@gmail.com beberapa daerah Jawa Barat dan Jawa Tengah, seperti Bogor, Karawang, Subang, Indramayu, Cirebon, Tegal dan Pekalongan (Damayanti 2010).

Penyakit mosaik kacang panjang masih sulit dikendalikan karena dapat ditularkan oleh vektor yaitu kutu daun (Aphis craccivora) (Susetio dan Hidayat 2011)dan bersifat tular benih. Benih kacang panjang komersial seperti varietas Parade, New Jaliteng, Long Silk, Pilar, 777, Maharani dan Lousiana belum bebas dari BCMV (Mahar 2012).

Salah satu alternatif pengendalian virus penyebab penyakit yaitu dengan aplikasi senyawa antiviral. Senyawa antiviral dapat diperoleh dari minyak atsiri (Zhao et al. 2016). Minyak atsiri serai (Cymbopogon citratus) berpotensi menghambat perkembangan Potyvirus asal nilam hingga $89,79 \%$ karena mengandung senyawa aktif seperti $\beta$ caryphyllene, linaly asetat, sabinene, timol, karvakrol, kariofilena oksida, linalool, karvon, dan geraniol (Mariana dan Noveriza 2013). Minyak atsiri serai perlu diujikan pada virus penyebab mosaik kacang panjang sehingga dapat diketahui efektivitasnya.

\section{METODE PENELITIAN}

Penelitian dilaksanakan mulai bulan November 2015 sampai bulan Juli 2016. Perbanyakan inokulum dilakukan di rumah kasa dan Laboratorium Hama Penyakit Tumbuhan (HPT), Fakultas Pertanian, Universitas Sebelas Maret (UNS) Surakarta sedangkan penanaman tanaman percobaan dilakukan di rumah kaca 
milik Laboratorium Pengamatan Hama dan Penyakit (LPHP) Sukoharjo.

Bahan yang digunakan dalam penelitian ini adalah isolat virus penyebab mosaik kacang panjang yang diperoleh dari lahan pertanian di Desa Joho, Kecamatan Mojolaban, Kabupaten Sukoharjo, tanaman Indikator Chenopodium amaranticolor, benih kacang panjang varietas Parade, minyak atsiri serai, tween 80 , buffer fosfat $\mathrm{pH} 7$, carborundum 600 mesh, Alkohol 70\%, akuadest, tanah steril sarung tangan dan cutton buds. Peralatan yang digunakan meliputi mortar, pistil, sprayer, polybag $30 \times 30 \mathrm{~cm}$, timbangan, cethok, ember dan gembor.

Percobaan menggunakan Rancangan Acak Lengkap (RAL) dengan 2 faktor. Faktor pertama adalah waktu aplikasi minyak atsiri serai yang terdiri atas 3 taraf yaitu $A 1=$ sebelum tanam (perendaman benih kacang panjang selama satu jam), A2=sehari sebelum inokulasi sap daun bergejala mosaik dan $A 3=$ sehari setelah inokulasi sap daun bergejala mosaik sedangkan faktor kedua adalah konsentrasi minyak atsiri serai yang terdiri atas 5 taraf yaitu $\mathrm{KO}^{*}=\mathrm{kontrol}$ negatif/tanaman sehat (konsentrasi $0 \%$ dan tanpa inokulasi virus), $\mathrm{KO}^{\star * *}=$ kontrol positif/tanaman sakit (konsentrasi $0 \%$ dengan inokulasi virus), $\mathrm{K} 1=$ konsentrasi $0,6 \%, \mathrm{~K} 2=$ konsentrasi $1,2 \%$ dan $\mathrm{K} 3=$ konsentrasi $\quad 1,8 \%$. Kedua faktor dikombinasikan sehingga diperoleh 15 perlakuan. Masing-masing kombinasi perlakuan diulang sebanyak 3 kali sehingga diperoleh 45 unit percobaan.
Pelaksanaan penelitian meliputi perbanyakan inokulum, persiapan media tanam, persiapan minyak atsiri serai, penanaman, aplikasi minyak atsiri serai, inokulasi sap daun kacang panjang bergejala mosaik secara mekanis, pemeliharaan tanaman dan panen. Peubah yang diamati yaitu masa inkubasi dan intensitas penyakit mosaik, waktu muncul bunga, bobot polong segar, bobot brangkasan segar dan bobot brangkasan kering kacang panjang. Data yang diperoleh dianalisis menggunakan uji $F$ 5\%, kemudian apabila berpengaruh nyata dilanjutkan dengan uji DMRT (Duncan Multiple Range Test) pada taraf nyata $5 \%$.

\section{HASIL DAN PEMBAHASAN}

\section{Masa Inkubasi Penyakit Mosaik Kacang Panjang}

Masa inkubasi merupakan tenggang waktu antara masuknya virus hingga timbulnya gejala pertama pada tanaman (Boss 1990). Tanaman kacang panjang yang terinfeksi virus penyebab mosaik tanpa aplikasi minyak atsiri serai menunjukkan gejala mosaik pada 5,44 HSI. Kebanyakan virus memerlukan waktu 2-5 hari untuk pindah dari daun yang diinokulasi (Agrios 2005). Waktu aplikasi minyak atsiri serai sebelum tanam (perendaman benih) dengan konsentrasi 1,8\% merupakan kombinasi perlakuan yang menunda kemunculan gejala mosaik (Gambar 1). Tanaman kacang panjang menunjukkan gejala mosaik pada $7,33 \mathrm{HSI}$.

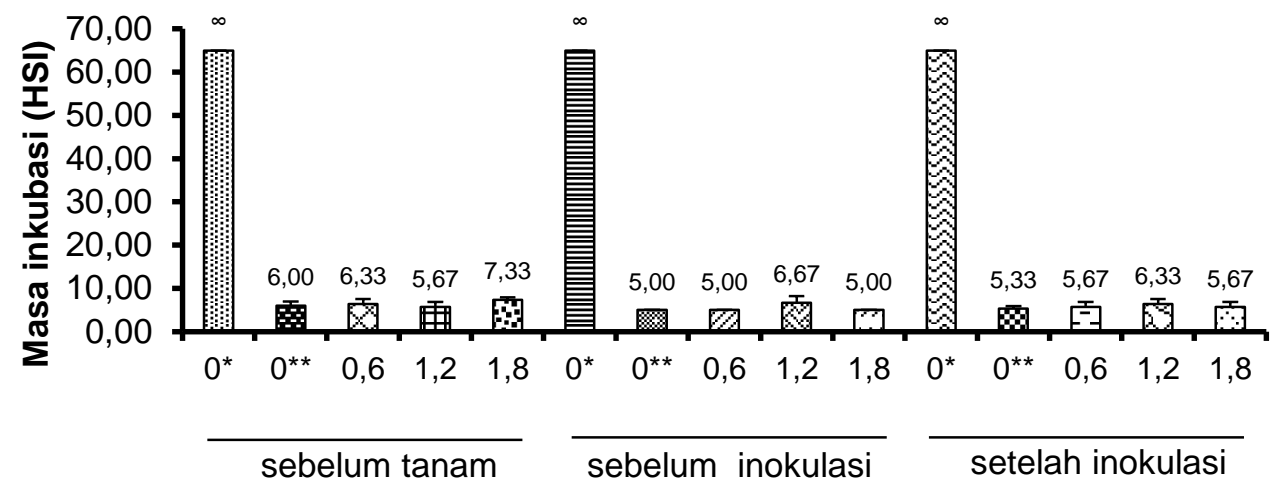

Waktu aplikasi dan konsentrasi minyak atsiri serai (\%)

$$
{ }^{*}=\text { kontrol negatif (tanaman sehat), }{ }^{* *}=\text { kontrol positif (tanaman sakit), HSI = Hari Setelah Inokulasi }
$$

Gambar 1. Pengaruh waktu aplikasi dan konsentrasi minyak atsiri serai terhadap masa inkubasi penyakit.

Mekanisme penundaan kemunculan gejala penyakit yang disebabkan oleh virus dari hasil perendaman benih dengan minyak atsiri serai belum diketahui dengan jelas. Tetapi pada penelitian sebelumnya, benih yang direndam pada minyak meniran meningkatkan vigor benih dan mampu mereduksi konsentrasi TMV
(Tobacco mosaic virus). Tanaman dengan konsentrasi virus yang rendah memiliki aktivitas peroksidase yang tinggi (Madhusudan et al. 2011). Aktivitas peroksidase yang tinggi telah dilaporkan sebagai bentuk respon ketahanan tembakau dari infeksi TMV (Matthews 1981 Cit. Hull 2002). Aktivitas senyawa antiviral dari 
minyak atsiri serai terhadap inaktivasi TMV dipengaruhi oleh konsentrasi yang digunakan (Min et al. 2013).

\section{Intensitas Penyakit Mosaik Kacang Panjang}

Intensitas penyakit adalah perbandingan antara bagian tanaman sakit dengan keseluruhan bagian tanaman baik sakit maupun sehat. Aplikasi minyak atsiri serai dengan berbagai konsentrasi mampu menghambat penyakit mosaik. Terlihat bahwa aplikasi minyak atsiri serai dengan konsentrasi $0,6 \%, 1,2 \%$ dan $1,8 \%$ memiliki pengaruh yang sama terhadap intensitas penyakit mosaik (Gambar 2).

Penghambatan penyakit mosaik pada kacang panjang diduga karena adanya aktivitas antiviral dari minyak atsiri serai. Hal ini didukung dengan penelitian sebelumnya bahwa senyawa monoterpen dari minyak atsiri serai masuk ke dalam sel tanaman sehingga menginaktifkan partikel TMV dan menghambat pembentukan kapsid (Min et al. 2013). Akan tetapi mekanisme dari minyak atsiri serai sebagai antiviral belum diketahui dengan pasti. Senyawa aktif $\beta$ Caryophyllene dan Germacrene $D$ (komponen Sesquiterpen) serta $\beta$-pinene dan limonene (komponen monoterpen) dari minyak atsiri Teucrium sp. memiliki pengaruh yang paling baik dalam menghambat perkembangan CMV (Bezic et al. 2011). Armaka et al. (1999) melaporkan bahwa aplikasi monoterpen seperti isoborneol mengakibatkan glikosilasi polipeptida terhambat sehingga glikoprotein tidak terdeteksi saat replikasi virus HIV-1.

: Penghambatan Intensitas Penyakit (\%)

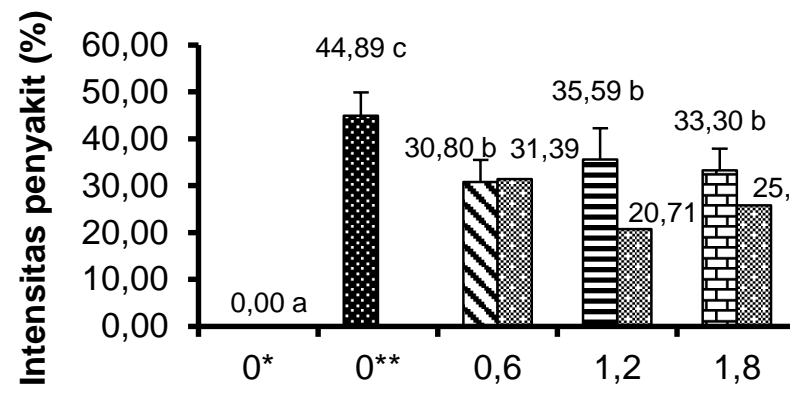

Konsentrasi minyak atsiri serai (\%)

${ }^{*}=$ kontrol negatif (tanaman sehat), ${ }^{* *}=$ kontrol positif (tanaman sakit), antarangka yang diikuti dengan huruf yang sama tidak berbeda nyata pada taraf $5 \%$, data ditransformasi dengan rumus Arc sin (SQRT(xi+0.5))

Gambar 2. Pengaruh konsentrasi minyak atsiri serai terhadap intensitas penyakit mosaik kacang panjang.

Tanaman kacang panjang terinfeksi virus penyebab mosaik yang diaplikasikan minyak atsiri serai, masih tetap menunjukkan gejala.
Keefektifan minyak atsiri dalam menekan infeksi virus dipengaruhi oleh jenis senyawa antiviral dan jenis virus yang dikendalikan (Dunkic et al 2010). Senyawa antiviral yang terkandung dalam minyak atsiri serai diantaranya $\alpha$-pinene $(6,38 \%)$, a-terpineol $(9,81 \%)$, limonene $(9,04 \%), \quad 1,8$ cineole $(6,88 \%)$, terpinolene $(10,67 \%)$, citronellal $(8,76 \%)$ dan lain sebagainya (Min et al 2013). Sementara itu, penyakit mosaik kacang panjang dapat disebabkan oleh beberapa jenis virus diantaranya BCMV-BIC dan CMV (Damayanti et al. 2009) dan MYMIV (Nurulita et al. 2015).

\section{Waktu Muncul Bunga Kacang Panjang}

Infeksi virus berpengaruh pada penurunan kadar hormon dan merangsang sintesis zat penghambat pertumbuhan. Akibatnya pembentukan bunga terhambat dan terjadi penurunan jumlah bunga yang dihasilkan (Agrios 2005). Aplikasi minyak atsiri serai pada berbagai konsentrasi tidak mempengaruhi waktu kemunculan bunga pada tanaman yang terinfeksi virus penyebab mosaik (Gambar 3). Tanaman kacang panjang varietas Parade yang terinfeksi BCMV tidak mengalami penundaan kemunculan bunga (Susetio dan Hidayat 2014). Terlihat bahwa kemunculan bunga pada tanaman yang diaplikasikan minyak atsiri serai konsentrasi 1,8\% lebih lama dibandingkan dengan tanaman yang diaplikasikan minyak atsiri serai konsentrasi $0,6 \%$ dan 1,2\% (Gambar 3). Hal ini dimungkinkan adanya aktivitas minyak atsiri serai terhadap sel tanaman. Jenis dan konsentrasi minyak atsiri yang digunakan dapat menjadi sitotoksik dalam sel eukariotik sehingga mempengaruhi membran sel dan organel sel (Bakkali et al. 2008).

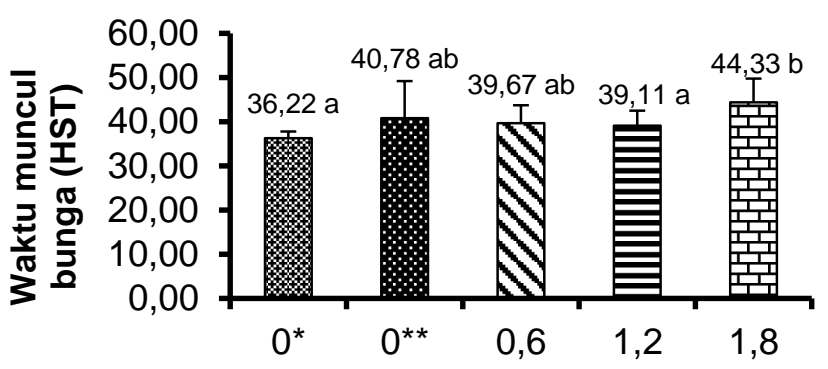

Konsentrasi minyak atsiri serai (\%)

${ }^{*}=$ kontrol negatif (tanaman sehat), ${ }^{* *}=$ kontrol positif (tanaman sakit), antarangka yang diikuti dengan huruf yang sama tidak berbeda nyata pada taraf $5 \%$

Gambar 3. Pengaruh konsentrasi minyak atsiri serai terhadap waktu muncul bunga kacang panjang. 


\section{Bobot Polong Segar Kacang Panjang}

Akibat infeksi virus BCMV pada 5 kultivar kacang panjang menyebabkan penurunan bobot polong segar 27,10-85,20\% (Susetio dan Hidayat 2014). Rata-rata bobot polong segar dari tanaman kacang panjang yang diaplikasikan minyak atsiri serai pada berbagai konsentrasi lebih rendah dibandingkan dengan kontrol positif, terlihat bahwa semakin tinggi konsentrasi minyak atsiri serai yang digunakan maka bobot polong segar kacang panjang semakin rendah (Gambar 4).

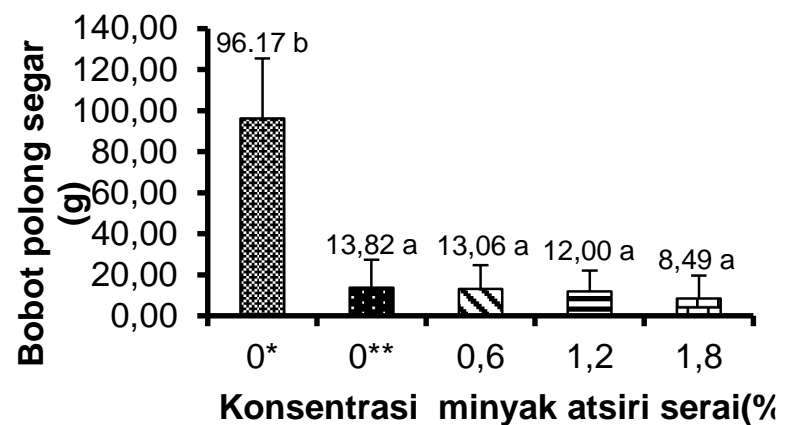

\section{Bobot Brangkasan Segar Tanaman Kacang Panjang}

Bobot brangkasan segar tanaman merupakan indikator yang menunjukkan tingkat serapan air dan unsur hara oleh tanaman untuk metabolisme (Dwidjoseputro 1994). Kombinasi perlakuan waktu aplikasi dan konsentrasi minyak atsiri serai yang berbeda tidak mempengaruhi bobot brangkasan segar tanaman. (Gambar 5). Jika dibandingkan dengan tanaman terinfeksi virus penyebab mosaik perlakuan
Keterangan: ${ }^{*}=$ kontrol negatif (tanaman sehat), ** = kontrol positif (tanaman sakit), antarangka yang diikuti dengan huruf yang sama tidak berbeda nyata pada taraf $5 \%$

\section{Gambar 4. Pengaruh konsentrasi minyak atsiri serai terhadap bobot polong segar kacang panjang.}

Infeksi virus menyebabkan penurunan fotosintesis melalui penurunan klorofil per daun, efisiensi klorofil dan luas daun per tanaman (Agrios 2005). Penurunan fotosintesis menyebabkan polong segar yang dihasilkan menjadi rendah. Intensitas penyakit mosaik tanaman yang diaplikasikan minyak atsiri serai lebih rendah dengan kontrol positif akan tetapi bobot polong segar yang dihasilkan tidak lebih tinggi dari kontrol positif. Hal ini dapat disebabkan karena tanaman memiliki gen perlawanan terhadap serangan patogen (Agrios 2005) sehingga kecepatan perkembangan dan penyebaran virus dapat ditekan (Subekti et al. 2006).

lainnya, aplikasi minyak atsiri serai konsentrasi $0,6 \%$ sebelum inokulasi sap daun bergejala mosaik menunjukkan bobot brangkasan segar yang tertinggi, sedangkan aplikasi minyak atsiri serai konsentrasi $1,8 \%$ sebelum tanam menunjukkan bobot brangkasan segar yang terendah (Gambar 5). Hasil tersebut sesuai dengan pengamatan bobot brangkasan kering (Gambar 6), tanaman dengan bobot brangkasan basah yang rendah memiliki bobot brangkasan yang rendah pula.

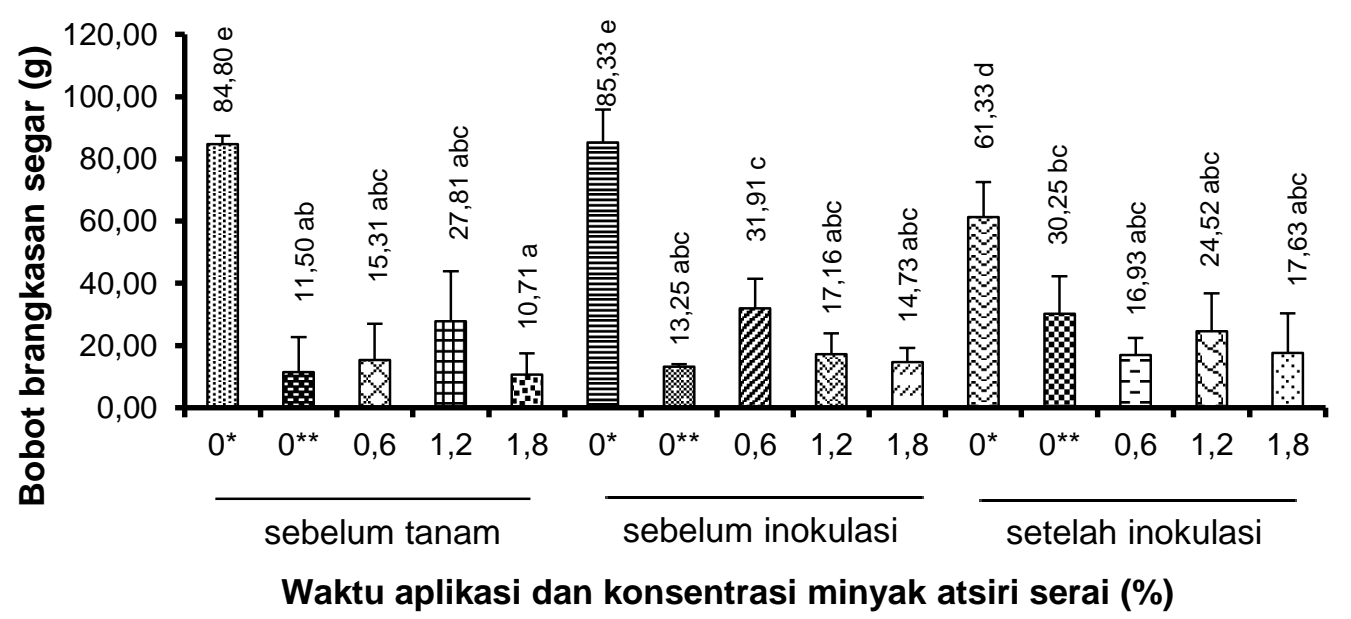
${ }^{*}=$ kontrol negatif (tanaman sehat), ${ }^{*}=$ kontrol positif (tanaman sakit), antarangka yang diikuti
dengan huruf yang sama tidak berbeda nyata pada taraf $5 \%$ 
Gambar 5. Pengaruh kombinasi waktu aplikasi dan konsentrasi minyak atsiri serai terhadap bobot brangkasan segar kacang panjang.

Bobot Brangkasan Kering Tanaman Kacang Panjang

Brangkasan kering merupakan bahan organik yang terdapat dalam bentuk biomassa, yang mencerminkan penangkapan energi oleh tanaman dalam proses fotosintesis. Semakin tinggi berat brangkasan kering menunjukkan bahwa proses fotosintesis berjalan baik (Hardjadi 1993). Aplikasi minyak atsiri tidak mempengaruhi bobot brangkasan kering

tanaman yang terinfeksi virus penyebab mosaik (Gambar 6). Rendahnya bobot brangkasan kering tanaman kacang panjang yang terinfeksi virus penyebab mosaik, baik yang diaplikasikan minyak atsiri serai disebabkan oleh adanya perbedaan ukuran dengan tanaman sehat. Infeksi virus pada tanaman menyebabkan terhambatnya laju pertumbuhan tanaman dan proses perluasan daun, penurunan hasil klorofil serta meningkatkan jumlah daun yang gugur (Yamacuchi 2008).

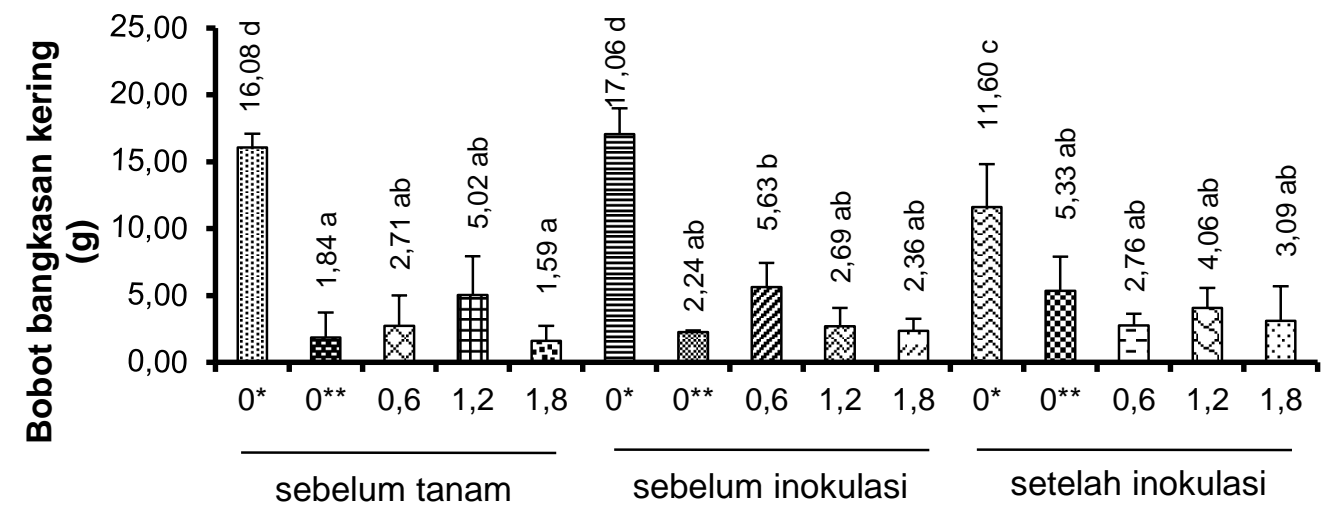

Waktu aplikasi dan konsentrasi minyak atsiri serai (\%)

${ }^{*}=$ kontrol negatif (tanaman sehat), ${ }^{* *}=$ kontrol positif (tanaman sakit), antarangka yang diikuti dengan huruf yang sama tidak berbeda nyata pada taraf $5 \%$

Gambar 6. Pengaruh kombinasi waktu aplikasi dan konsentrasi minyak atsiri serai terhadap bobot kering tanaman kacang panjang. 
Aplikasi minyak atsiri serai dengan waktu aplikasi dan konsentrasi yang berbeda memiliki pengaruh yang sama terhadap bobot brangkasan segar dan kering tanaman yang terinfeksi virus penyebab mosaik. Aplikasi minyak atsiri serai sebelum tanam (perendaman benih) dan sebelum inokulasi sap daun bergejala mosaik cenderung memiliki bobot brangkasan segar dan kering tanaman kacang panjang terinfeksi virus penyebab mosaik yang lebih tinggi (Gambar 5 dan Gambar 6). Hal ini dimungkinkan di dalam tanaman kacang panjang sudah terdapat senyawa antiviral dari minyak atsiri serai sebelum terjadi infeksi virus penyebab mosaik. Mariana dan Noveriza (2013) menyebutkan bahwa perkembangan Potyvirus pada C. amaranticolor dapat dihambat dengan aplikasi minyak astisiri serai sebelum inokulasi Potyvirus.

Penundaan kemunculan gejala mosaik dan penurunan intensitas penyakit oleh minyak atsiri serai belum memperbaiki waktu kemunculan bunga, bobot polong segar, bobot brangkasan segar dan kering. Hal ini menandakan bahwa penggunaan minyak atsiri serai sebagai bahan antiviral terhadap virus penyebab mosaik kacang panjang belum efektif. Namun, penelitian sebelumnya dijelaskan bahwa minyak atsiri serai memiliki peranan untuk mengobati penyakit yang disebabkan oleh TMV (Min et al. 2013).

\section{KESIMPULAN}

Berdasarkan hasil penelitian dapat disimpulkan sebagai berikut:

1. Aplikasi minyak atsiri konsentrasi 1,8\% sebelum tanam (perendaman benih kacang panjang) menunda kemunculan gejala mosaik.

2. Penggunaan minyak atsiri serai dengan berbagai konsentrasi $(0,6 \%, 1,2 \%$ dan $1,8 \%)$ pada kacang panjang mampu menurunkan intensitas penyakit mosaik hingga $31,39 \%$.

3. Penundaan kemunculan gejala dan penurunan intensitas penyakit mosaik oleh minyak atsiri serai belum mampu memperbaiki pertumbuhan dan perkembangan kacang panjang.

\section{UCAPAN TERIMAKASIH}

Penulis mengucapkan terima kasih kepada Laboratorium Pengamatan Hama dan Penyakit (LPHP) Sukoharjo yang telah membantu fasilitas dalam penelitian ini.

\section{DAFTAR PUSTAKA}

Agrios, GN., 2005, Plant pathology $5^{\text {th }}$ ED, London(UK) : Elsevier Academic Press.

Armaka, M., Papanolaou, E., Sivropulou, A., Arsenakis, M. 1999, Antiviral properties of isoborneol, a potent inhibitor of herpes simplex virus type 1, Antiviral Res, 43 : 79-92, DOI:10.1016/S0166-3542(99)00036-4.
Bakkali, F., Averbeck, S., Averbeck, D., Idaomar, M. 2008, Biological effects of essential oils - a review, J Food and Chemical Toxiology, 46 : 446-475, DOI:10.1016/j.fct.2007.09.106.

Bezic, N., Dunkic, V., Vuko, E., Ruscic, M., Blazevic, I., Burcul, F. 2011, Antiphytoviral activity of sesquiterpene-rich essential oils from four croatian teucrium species, Molecules, 16 : 8119-8129, DOI:10.3390/molecules16098119.

Bos, L. 1994, Pengantar virologi tumbuhan, Yogyakarta(ID) : Gadjah Mada University Press.

Damayanti, TA. 2010, Kajian sifat bioekologi dan biomolekuler penyebab outbreak penyakit kuning pada kacang panjang di Jawa Barat dan Jawa Tengah, http://repository.ipb.ac.id, Diakses pada tanggal 12 Juli 2016.

Damayanti, TA., Alabi, OJ., Naidu, RA., Rauf, A. 2009, Severe outbreak yellow mosaic disease on the yard long bean in Bogor, West Java, Hayati J Bios, 16(2) : 78-72, DOI:10.4308/hjb.16.2.78.

Dunkic, V., Bezic, N., Vuko, E., Cukrof, D. 2010, Antiphytoviral activity of Satureja montana L. ssp. variegata (Host) P.W. ball essential oil and phenol compounds on CMV and TMV, Molecules, 15 : 67136721, DOI: 10.3390/molecules 15106713.

Dwidjoseputro, D. 1994, Pengantar Fisiologi Tumbuhan, Jakarta(ID) : Gramedia Pustaka Utama.

Hardjadi, SS. 1993, Pengantar Agronomi, Jakarta(ID) : PT Gramedia.

Hull, R. 2002, Mattews' Plant Virology $4^{\text {th }} E D$, California(LA) : Academic Press.

Kementrian Pertanian, 2016, Produksi sayuran Indonesia, http://www.pertanian.go.id. Diakses pada tanggal 01 Maret 2016.

Madhusudan, KN., Vinayarani, G., Deepak, SA., Niranjana, SR., Prakash, HS., Singh, GP., Prasad, BC. 2011, Antiviral activity of plant extracts and other inducer against Tobamo viruses infection in Bell Pepper and Tomato Plants, Int J Plant Pathol, 2-8, DOI :10.3923/ijpp.2011.

Mahar, AW. 2012, Deteksi serologi Bean Common Mosaic Virus (BCMV) dari benih kacang panjang (Vigna sinensis L.) komersial dan petani (Abstr), http://repository.ipb.ac.id/.

Mariana, M., Noveriza, R. 2013, Potensi minyak atsiri untuk mengendalikan Potyvirus pada tanaman Nilam, J Fitopatol, 9(2) : 53-58, DOI:10.14692/jfi.9.2.53. 
Min, L., Han, Z., Xu ,Y., Yao, L. 2013, In vitro and in vivo anti-Tobacco mosaic virus activities of essential oils and individual compunds, J Microbiol Biotechnol, 23(6) : 771-778, DOI:10.4014/jmb.1210.10078.

Nurulita, S., Sri, HH., Kikin, HM., Thomas, J. 2015, Molecular characterization of begomovirus invecting yard long bean (Vigna unguiculata subp sesquipedalis L.) in Java, Indonesia, Biotropia, 22(1) : 53-60, DOI: 10.11598/btb.2015.22.1.401.

Rosmarkam, A., Yuwono, NW. 2011, Ilmu Kesuburan Tanah, Yogyakarta(ID) : Kanisius.

Subekti, D., Hidayat, SR., Nurhayati, E., Sujiprihati, S. 2006, Infeksi Cucumber mosaic virus dan Chili veinal mottle virus terhadap pertumbuhan dan hasil tanaman cabai, Hayati, 13(2) : 53-57, URL:http://dx.doi.org/10.4308/hjb.13.2.53.

Susetio, H., Hidayat, SH. 2014, Respons lima varietas kacang panjang terhadap Bean common mosaic virus, J patol, 10(4) : 112118, DOI:10.14692/jfi.10.4.112.

Susetio, H., Hidayat, SH. 2011, Penyakit mosaik kuning kacang panjan: respon varietas kacang panjang (Vigna sinensis L.) dan efisiensi penularan melalui kutu daun (Aphis craccivora Koch), Skripsi, Institut Pertanian Bogor.

Whenham, RJ., Fraser, RSS., Brown, LP., Payne, JA. 1986, Tobacco-mosaic-virus induced increase in abscisic-acid concentration in tobacco leaves: intracellular location in light and dark-green areas, and relationship to symptom development, Planta, 168 : 592-598, DOI:10.1007/BF00392281.

Yamacuchi, A. 2008, Viral lesion formation on chlorophyll deficient leaf area, J Phytopathol, 61(4) : 399-400, DOI: 10.1111/j.14390434.1968. tb02342.

Zhao, L., Feng, C., Wu, K., Chen, W., Chen, Y., Hao, X., Wu, Y. 2016, Advances and prospect in biogenic subtances againts plant virus : a review, J pestbp, 1-8, DOI:10.1016/j.pestbp.2016.07.003. 